\title{
INVESTIGATION OF EMOTIONAL INTELLIGENCE AND EMPATHY IN THE SIBLINGS OF CHILDREN WITH AUTISM SPECTRUM DISORDER
}

\author{
Authors: \\ Anna Szabina Szele \\ University of Debrecen (Hungary) \\ Judit Inántsy-Pap (Ph.D.) \\ University of Debrecen (Hungary) \\ E-mail address of first author: \\ szele.anna@ped.unideb.hu
}

Lectors:

\author{
Ildikó Petó (Ph.D.) \\ University of Debrecen (Hungary) \\ Karolina Eszter Kovács (Ph.D.) \\ University of Debrecen (Hungary)
}

Szele, Anna Szabina \& Inántsy-Pap, Judit (2021). Investigation of Emotional Intelligence and Empathy in the Siblings of Children with Autism Spectrum Disorder. Különleges Bánásmód, 7. (1). 59-68. DOI $\underline{10.18458 / K B .2021 .1 .59}$

\begin{abstract}
In recent years, more and more researchers have focused on studies of children with autism spectrum disorder (ASD), however, studying their siblings has gained less scientific interest. The present study focuses on siblings of children with ASD and assesses their characteristics in terms of emotional intelligence and empathy. Our sample consisted of $n=61$ children in two age groups studied: 6-8 and 1015 years old. Our experimental group consisted of $n=30$ siblings of children with ASD, while our control group also consisted of $\mathrm{n}=31$ children with sibling relationships. Subjects completed two paper-andpencil tests: the Reading the Mind in the Eyes Test (Children's Version), and depending on the age group, the Emotional Intelligence Test (EIT 6-8 / EIT 10-15). We identified higher emotional intelligence and empathy in higher age groups. Among 6-8 years old siblings of children with ASD, higher scores were found to be. At the level of gender differences, girls performed more outstandingly in the tests examined. In our study, the 6-8 years old siblings of children with ASD can be characterized by a higher degree of emotional intelligence and empathy, however, we cannot draw conclusions in a representative way for the entire population.
\end{abstract}

Keywords: emotional intelligence; empathy; siblings; autism

Disciplines: psychology

\section{Absztrakt \\ ÉRZELMI INTELLIGENCIA ÉS EMPÁTIA VIZSGÁLATA AUTIZMUSSAL ÉLŐK TESTVÉREI KÖRÉBEN}

Az utóbbi évek kutatásaiban az autizmussal élő gyermekek vizsgálata egyre nagyobb hangsúlyt kapott, azonban a velük sorsközösségben élő testvéreik vizsgálata kevésbé szerzett tudományos érdeklődést. Jelen tanulmány az autizmussal élő gyermekek testvéreire fókuszál, és az érzelmi intelligencia és empátia 
vonatkozásában méri fel jellegzetességeiket. Mintánkat összesen $n=61$ gyermek alkotta két vizsgált korosztályban: 6-8 és 10-15 éves életkorban. Vizsgálati csoportunkat $n=30$ autizmussal éló gyermek testvére képezte, míg kontrollcsoportunkat szintén testvérkapcsolattal rendelkező gyermekek $n=31$ alkották. A vizsgálatban résztvevő gyermekek két tesztet töltöttek ki, a „Szemből olvasás tesztet”, valamint korcsoporttól függóen a „Képes érzelmi intelligenciatesztet (EIT 6-8/EIT 10-15)”. Magasabb életkori csoportokban magasabb érzelmi intelligenciát és empátiás készséget azonosítottunk. Az autizmussal élők 6-8 éves testvérei körében magasabb pontszámokat tapasztaltunk mindkét teszt vonatkozásában. A nemi különbségek szintjén a lányok kiemelkedőbben teljesítettek a vizsgált feladatokban. Jelen vizsgálat keretein belül, az autizmussal élő gyermekek 6-8 éves testvérei az érzelmi intelligencia és empátiás készség magasabb fokával jellemezhetőek, eredményeinkből azonban nem következtethetünk reprezentatív módon a teljes populációra.

Kulcsszavak: érzelmi intelligencia, empátia, autizmus, testvérek

Diszciplína: pszichológia

Since the first description of autism (Kanner, 1943), science has been developing dynamically: a number of articles, books, and journals have been published about autism spectrum disorder. However, scientific research pays more attention to children with autism than to their parents and siblings. In our study, we tried to investigate whether in the emotional life of siblings, the autism is considered as a disadvantage, or vice versa, it helps the siblings to a higher degree of emotional intelligence, to understand other people's emotions more easily. The aim of our study was to examine the emotional intelligence and empathy among siblings of children with ASD. Reviewing both the international and Hungarian literature, it can be said that this is an underinvestigated research area.

This paper presents the results of our previous study. In the sections presenting the theoretical background, we describe the psychological definitions and models of emotional intelligence and empathy. Then we describe our main results of the research conducted. Our aim is providing a comprehensive picture of the possible negative or positive emotional and developmental characteristics of siblings of children with ASD.
The analysis follows three research questions, the description of results, and the discussion synthesize the study.

\section{Emotional intelligence and empathy}

Emotional intelligence is a set of abilities that elevates the level of the contribution of emotions to adaptation to the highest level (Oláh, 2005). This concept began to develop when two scientific journals published articles on the subject; however, for a long time, the research of intelligence and emotion were two separate areas (Mayer, Di Paolo and Salovey, 1990; Salovey and Mayer, 1990; Oláh, 2005). John D. Mayer and Peter Salovey developed a formal theory and method of measuring emotional intelligence (Mayer, 2003).

The concept is usually applied by professionals in three different ways (contexts) (Oláh, 2005):

Cultural trend (as an intellectual or emotional current) that characterizes a given age.

A group of personality traits that is important for a successful life, such as perseverance, selfdiscipline, social skills, and performance motivation. 
The set of abilities that are used in the processing of emotional information.

Several definitions can be found in the literature to describe emotional intelligence, which, despite their differences, can be divided into two broad groups. According to the ability model, emotional intelligence includes the ability to perceive, express, understand and manage emotions, the ability to control them and use them to our personal development (Kádár, 2012), while the mixed emotional intelligence models define the construct as a combination of personality traits, mental abilities, social competencies, and motivational factors (Nagy, 2012).

Empathy has recently become the subject of scientific interest again. It has been a neglected area for years because it has not been considered an important aspect of human nature (Zahn-Waxler and Radke-Yarrow, 1990). According to the definition of Baron-Cohen, empathy is a power to identify the emotions and thoughts of others and to respond to their emotional responses with the appropriate emotion (Baron-Cohen, 2006). With its help, we are able to understand other people better and we can more easily predict their behaviour. It involves recognizing the feelings and emotional states of others and responding to them (BaronCohen, 2006).

Many different ideas have emerged about both its concept and its development (e.g., Freud, 1958; MacLean, 1985). Martin Hoffmann believed that no matter how old a child is, he/she can feel empathy for peers, and as he/she gets older, it can be more sophisticated and differentiated. Hoffmann identified four different stages in the development of empathy (Hoffmann, 1991).

Differences in the ability of empathy by gender can be detected already in the very early ages of life (Baron-Cohen, 2006). According to the literature, the empathic ability of men is lower than that of women, the development of the ability itself is slower, and further development stops earlier (Buda, 2006). Women are able to more accurately identify facial expressions and interpret nonverbal communication - even the slightest change in tone and facial expressions are discovered and used in mind reading (Baron-Cohen, 2006).

\section{The special situation of siblings of children with ASD}

Siblings play a special role in the lives of children with autism. They live in a 'community of shared destiny' with the affected person. They inspire them to take important developmental steps, helping them to acquire basic skills. In many cases, they are not in the same age, but the bond between them is biologically unbroken (Volkmar and Wiesner, 2013).

However, the behaviour of children with autism can often be frightening or violent, which may strongly influence the sibling relationships. Physical violence is a frightful experience at home, and it may suggest to the sibling that it is not safe. $\mathrm{He} / \mathrm{she}$ may feel defenceless himself/herself (Benderix and Sivberg, 2007). The age of the child with autism, as well as the amount of the required help and care and whether they receive it in their home or a separate specialized institution, can also affect the relationship. If parents spend most of their time caring for a child with autism, the sibling may feel neglected (Volkmar and Wiesner, 2013).

Some studies suggest that siblings of children with ASD are more likely to have emotional, adjustment problems, and imbalances (BaronCohen and Bolton, 2000), social, communication disabilities, language problems such as delayed language development may occur (Bailey et al., 1998). Although these characteristics do not reach the diagnostic level, they may affect early development and learning (Stone et al., 2007). Meta-analytical study of Garrido et al. (2017) identified lower language and motor development, 
while Stone, McMahon, Yoder and Walden's (2007) study identified significantly lower socialcommunication and cognitive abilities. They showed poorer performance in nonverbal problem solving, focusing attention, understanding words and sentences, using gestures, and socialcommunicative interactions with their parents. Lovell and Wetherell (2017) identified several emotional problems and depressive symptoms among them.

However, autism does not necessarily have a negative impact on siblings in all cases. Some research suggests that the siblings develop greater sensitivity toward disabilities and their fellowcreatures, they are more empathetic and value their health better than their peers (Baron-Cohen and Bolton, 2000). Research by Roeyers and Mycke (1995) found siblings of children with ASD to be much more accepting and blushing, while others reported less conflict (Kaminsky and Dewey, 2001; Fisman et al., 1996) and greater warmth in the sibling relationships (Fisman et al., 1996). In many cases, these children view their sibling relationships positively (Bägenholm and Gillberg, 1991; Kaminsky and Dewey, 2001; McHale, Sloan and Simeonsson, 1986; Roeyers and Mycke, 1995), they are proud to be able to teach their siblings with autism (Bristol and Schopler, 1984). The research of Benderix and Sivberg (2007) highlights that, depending on the age and the family, siblings have different experiences of responsibility and empathy for their siblings with autism. Some feel obligated to protect their siblings with autism and, in part, take responsibility from their parents. In many cases, they empathise with their siblings with autism, especially when they notice that the sibling is afraid, sad or frustrated by something.

As noted above, there is no clear consensus in the literature regarding siblings of children with ASD. This is why we considered it an interesting issue to examine siblings' emotional intelligence and empathy.

\section{Method}

Our study aims to describe the characteristics of emotional intelligence and empathy among siblings of children with ASD. During the investigation, we sought to answer the following questions:

1. Are there significant differences in emotional intelligence and empathy between each age groups (6-8 and 10-15)?

2. What emotional intelligence and empathy can be characterized among the siblings of children with ASD compared to the control groups?

3. Concerning gender differences, can we identify significant differences between boys and girls?

\section{Sample}

Our sample consists of 61 children - the main inclusion criteria was the age between 6-8 and 1015 years, as well as the experience of a sibling relationship. The tests were completed by 30 children in the group of siblings of children with ASD, while in the control group 31 siblings of children with typical development were assessed. The gender distribution of the experimental and control groups was nearly balanced: in the experimental group there were seven boys and eight girls in the 6-8 years old age group $(n=15)$ and nine boys and six girls in the 10-15 years old age group $(n=15)$. For the control groups, eight boys and eight girls in the 6-8 years old age group $(n=16)$ and seven boys and eight girls in the 10-15 years old age group $(n=15)$ completed the tests. Data collection took place in 2015 and was part of a previous workshop (Szele, 2015). The study sample consisted of students living in Békés, Csongrád, Hajdú-Bihar, Heves, Jász-NagykunSzolnok, Komárom-Esztergom, Pest and SzabolcsSzatmár-Bereg counties of Hungary. 


\section{Procedure}

Two paper-and-pencil tests were used for data collection. Participation in the research was voluntary, and informed consent was obtained from the parents of subjects. For statistical analysis, we used the RStudio statistical program.

\section{Methods}

The test completion took approximately 30 to 45 minutes, which also required the help of an adult in each case. Every participant received an answer sheet for the solutions.

1. Emotional Intelligence Test for 6-8 years old (EIT 68). The development of the series of Emotional Intelligence Test in Hungary is related to Henriett Nagy. It is based on the sets of tasks measuring social competence and emotional intelligence developed jointly with Attila Oláh and Kinga Tóth (2005/a; 2005/b). The version for 6-8 years old has 19 items with a maximum of 19 points. The test consists of three types of tasks. In the first type, the child sees an emotional target image and five emotional portraits, and his/her task is to choose the only one that expresses their own feelings properly (see Figure 1).
The second type consists of an emotional target image and emotional portraits of five different children: the subject has to select the image of the child who is likely to be present in the scene described by the target image. In the third type of tasks, children see five portraits of adults and children expressing different emotions. Their task is to link adult and child portraits expressing similar emotions (Nagy, 2010).

\section{Emotional Intelligence Test for 10-15 years old (EIT} 10-15). For the 10-15 years old age group, the test contains 29 items, and a total of 29 points can be obtained. The set of tasks is structured in a similar way to the version of 6-8 year olds - it includes the first two types of tasks mentioned above but is also supplemented by more complex tasks. The subjects have to select one of the possible images that expresses the same emotion and state as the target photos, based on the photos expressing different non-verbal signs. Furthermore, the test was extended with tasks in which they have to imagine certain situations and emotional states based on the photos (Nagy, 2010).

Figure 1. Example from the first type of tasks of EIT 6-8 (source: Nagy, 2010, p. 60.)

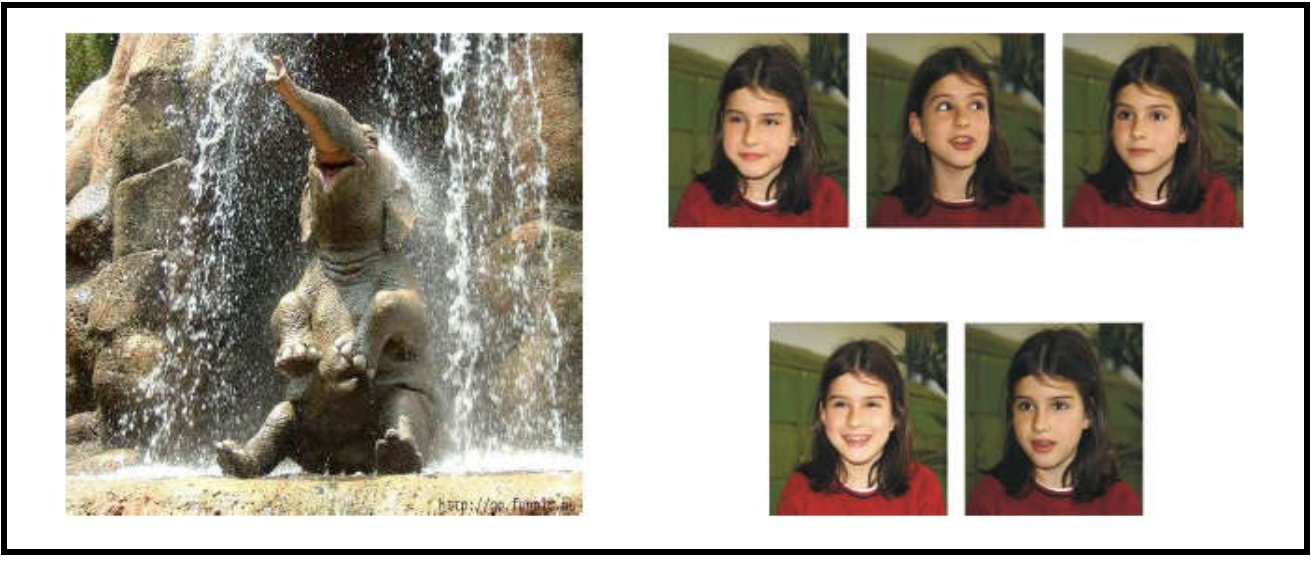


3. Reading the Mind in the Eyes Test (Children's Version), RMET-C

Baron-Cohen, along with Sally Wheelwright, developed the Reading the Mind in the Eyes Test (Children's Version) to measure empathy (BaronCohen et al., 2001). During the completion of the test, the participant is presented with a series of photographs of only the eye regions of different faces to make the solution more challenging and gender differences more visible.

For each item, a photograph is framed with four words that describe the possible feeling of the person (see Figure 2). The subject has to choose one word that describes the feelings or thoughts of the person in the most appropriate way. The child version of the test consists of 28 items (BaronCohen, 2006), the instructions of the original English version were translated into Hungarian.

Due to the two versions of EIT (6-8 / 10-15), we used a between-subject arrangement in our study. Our two dependent variables were the 'emotional intelligence' and the 'empatby', our independent variables were the 'age' (6-8 / 10-15) and the 'gender' (boy / girl).

\section{RESULTS}

Before the main statistical analysis, the normality of the sample was calculated by the Shapiro-Wilk test. Most of our data did not follow a normal distribution, so non-parametric tests were carried out. Mann-Whitney tests were used for group and gender comparisons, while Spearman's rank correlation method was used to examine the correlation between the two dependent variables.

\section{Comparison of the examined age groups based on the results of RMET-C}

In our analyses, we compared the empathic skills of the 6-8 and 10-15 age groups. The MannWhitney test $(W=48.5 ; p=.0073)$ identified a significant difference between the two age groups, which was also shown at the level of medians, the 10-15 years old group of siblings of children with ASD (median of $19 \pm$ a standard deviation of 1.84) performed better than 6-8 years old (17 \pm 3.36$)$. We also examined the significance of the age differences in the control groups, and found a significant difference $(W=30.5 ; p=.0003)$ between the older and younger age groups, too.

Figure 2. Example from the Children's Version of the Reading the Mind in the Eyes Test (source: https:// wnw.autismresearchcentre.com/tests/ eyes-test-child/)

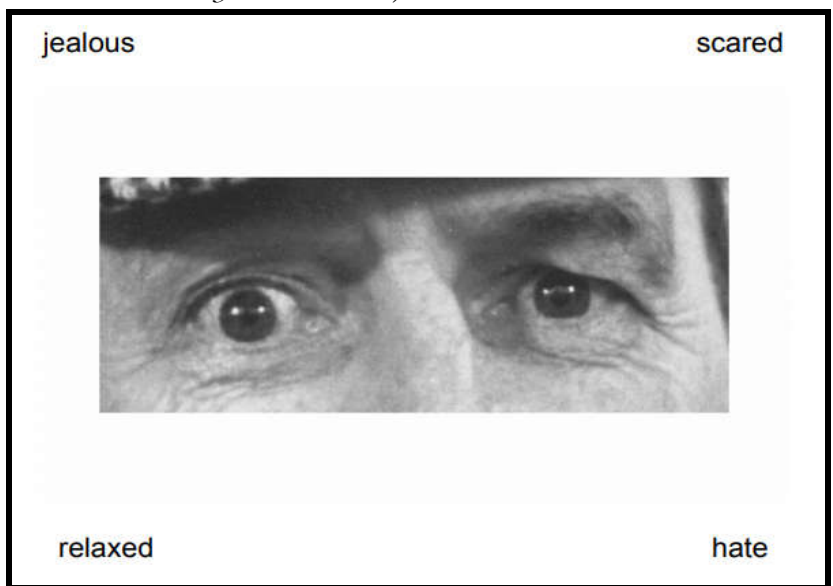


The median values confirmed that the higher age group of the control group (19 \pm 3.27$)$ also performed better in the RMET-C than 6-8 years old (12 \pm 3.59$)$, examining the empathy

Comparison of the results of experimental and control groups (emotional intelligence and empathy)

In our study, we sought to answer whether siblings of children with ASD performed better in terms of emotional intelligence and empathy, or there was no outstanding difference in their performance to the control group. In the 6-8 years old age groups, the results of the Mann-Whitney test for EIT $(W=154.5 ; p=.1667)$ showed no significant difference between the experimental and control groups. However, regarding the RMET-C significant difference was identified $(W=188 ; p=$ .0068) between the two groups. Examining the median values (see Figure 3), it can be observed that siblings of children with ASD achieved higher scores in both tasks. However, in the 10-15 age group, the result of the Mann-Whitney test showed no significant differences between the two groups neither for the EIT variable $(W=121 ; p=.7209)$ nor for the RMET-C variable $(W=128.5$; $p=$ .5014).
Since both the 6-8 and 10-15 years old age groups completed the same children version of the RMET-C, we considered it to be appropriate to integrate these results. Based on the results of the Mann-Whitney test $(W=615 ; p=.0296)$, there was a significant difference between the experimental and control groups, which is also shown at the level of medians in favour of siblings of children with ASD $\left(\operatorname{Med}_{\text {exp }}=18 ; \operatorname{Med}_{\text {contr }}=16\right)$.

We also examined the correlation between emotional intelligence and empathic skill in the two age groups. However, Spearman's rank correlation method showed no significant correlations between the two variables (6-8 years old: $r=.2636$, $p=.3424 ; 10-15$ years old: $r=-.0455, p=.8719)$.

\section{Gender differences in emotional intelligence (EIT) and empathy (RMET-C)}

Using Mann-Whitney tests, we examined the gender differences in emotional intelligence and empathy scores, respectively. Based on the statistical results, we cannot conclude a significant difference between boys and girls in either group. However, examining the medians, there is a tendency for girls to perform better compared to boys of the same age group (see Table 1).

Figure 3. Comparison of the results of the emotional intelligence test (EIT 6-8) and empatby test (RMET-C) of 6-8 age groups (source: the Authors)

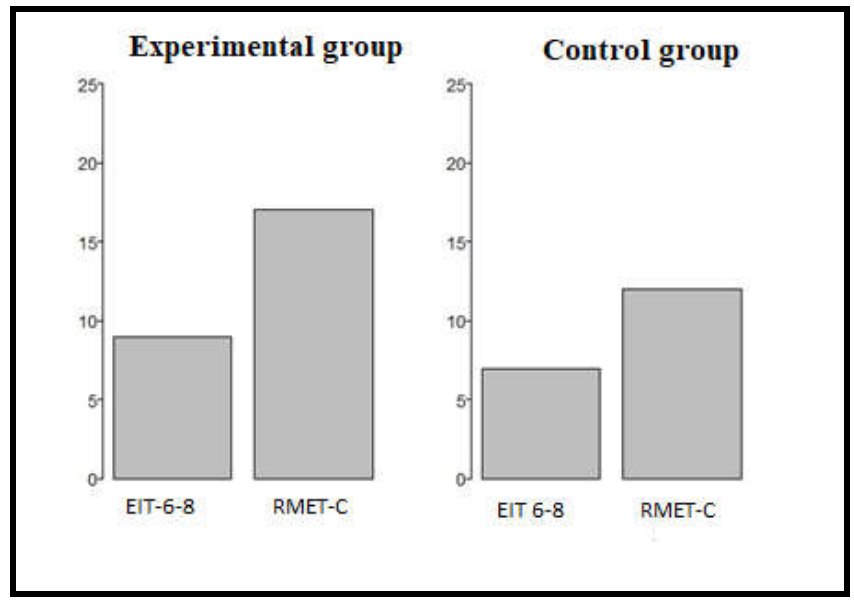


Table 1. Gender differences, Med (SD) (source: the Authors)

\begin{tabular}{ccccccccc}
\hline \multirow{2}{*}{ Ages } & \multicolumn{3}{c}{ Experimental group } & \multicolumn{3}{c}{ Control group } \\
\cline { 2 - 9 } & \multicolumn{2}{c}{ EIT } & \multicolumn{2}{c}{ RMET-C } & \multicolumn{2}{c}{ EIT } & \multicolumn{2}{c}{ RMET-C } \\
\cline { 2 - 9 } & Boy & Girl & Boy & Girl & Boy & Girl & Boy & Girl \\
\hline 6-8 years old & $7(1.70)$ & $10(2.47)$ & $16(2.62)$ & $18(3.87)$ & $7(1.51)$ & $8(2.03)$ & $10.5(3.33)$ & $13(4.06)$ \\
\hline 10-15 years old & $17(2.20)$ & $17,5(2.52)$ & $19(2.06)$ & $19(1.64)$ & $12(4.19)$ & $18(1.06)$ & $19(3.62)$ & $19,5(2.87)$ \\
\hline
\end{tabular}

\section{Discussion}

In the statistical analysis of our study, we examined the effect of age differences in the Reading the Mind in the Eyes Test (RMET-C), a tool for measuring empathic skill. Based on its results, it can be said, both in the experimental and both in the control group, that the 10-15 years old children performed better than their smaller counterparts. Age advantage was associated with higher emotional intelligence and empathic skills.

Subsequently, we compared the results of the experimental and control groups. Based on the literature, we hypothesized that siblings of children with ASD are characterized by higher emotional intelligence and empathic skills. In the 6-8 age groups, we did not find a significant difference concerning emotional intelligence between the experimental and control groups, but a significant difference was identified in empathy. Examining the medians, it became unambiguous that siblings of children with ASD performed better than the control group. Our results are consistent with literature findings according to which siblings of children with ASD being more compassionate and accepting (e.g., Baron Cohen and Bolton, 2000; Roeyers and Mycke, 1995; Ward et al., 2016). However, in case of the 10-15 years old age group, there was no difference between the experimental and control groups concerning either emotional intelligence or empathic skills. At the level of medians, we identified similar performances.

We assessed the performance not only at the level of groups/age groups, but we also combined an integrated group from the age groups. We hoped that the partial result detected would be more prominent in a larger sample. As the RMETC was the same for all age groups, these data were used for comparison. Based on the results of the Mann-Whitney test and the medians, we can conclude that the combined group of siblings of children with autism performed better in the empathy measurement task compared to the control group.

We also examined the correlation between emotional intelligence and empathy. However, we did not find a significant correlation in this regard. Finally, we examined gender differences in emotional intelligence and empathy. Although there were no significant differences, at the level of medians (see Table 1), a positive trend could have been detected in favour of girls.

\section{Limitations}

The potential limitations of our study were the small sample size and the lack of the assessment of the severity of autism. Due to the broad spectrum of autism, it is extremely individual-specific what causes problems and difficulties in everyday life; as a result, families and siblings also face different situations. Our research did not assess the age, the number of siblings and the quality of the relationship between them (e.g. amount of time spent together). We would recommend a more detailed examination of these variables for the design and implementation of further research. 


\section{Conclusions}

With our statistical analysis we cannot unequivocally conclude that siblings of children with ASD performed better in all the examined indicators - however, the opposite has not been proved either. Consequently, we cannot conclude that siblings of children with ASD have any disadvantages in the measured variables. At the level of medians, however, the difference between age groups is remarkable as in the 6-8 years old group, siblings of children with ASD achieved higher scores than members of the control group. Considering these data and the increasing trend observed in the case of gender differences, we would conclude that by increasing the number of the sample, our results would be more significant. Our results cannot be considered representative due to the characteristics of the sample, so we recommend the reader to keep in mind the main limitations of the study when interpreting the results. In the further research, it would be worthwhile to examine the emotional intelligence and empathy in the siblings of other types of children with disabilities to investigate the main differences and similarities among them. Furthermore, our results can be informative to professionals who work with siblings of children with disabilities and develop them individually.

\section{References}

Bägenholm, A., \& Gillberg, C. (1991). Psychosocial effects on siblings of children with autism and mental retardation: A population-based study. Journal of Mental Deficiency Research, 35, 291-307. doi. 10.1111/ j.1365-2788.1991.tb00403.x.

Bailey A., Palferman S., Heavey L., \& Le Couteur A. (1998). Autism: the phenotype in relatives. Journal of Autism and Developmental Disorders, 28, (5), 369-392.

Baron-Cohen, S. (2006). Elemi kïlönbség. Férfiak, nôk és a szélsöséges férfiagy. Budapest: Osiris Kiadó.

Baron-Cohen, S., \& Bolton, P. (2000). Autizmus. Budapest: Osiris Kiadó.

Baron-Cohen, S., Wheelwright, S., Scahill, V., Lawson, J., \& Spong, A. (2001). Are intuitive physics and intuitive psychology independent? A test with children with Asperger Syndrome. Journal of Developmental and Learning Disorders, 5, 47-78.

Benderix, Y., \& Sivberg, B. (2007). Siblings' Experiences of Having a Brother or Sister With Autism and Mental Retardation: A Case Study of 14 Siblings From Five Families. Journal of Pediatric Nursing, 22, (5), 410-418. doi. 10.1016/j.pedn.2007.08.013

Bristol, M. M., \& Schopler, E. (1984). A developmental perspective on stress and coping in families of autistic children. In: Blacher, J. (Ed.): Severely handicapped young children and their families (pp. 91-141). Orlando, FL: Academic Press.

Buda B. (2006). Empátia. A beleélés lélektana. Folyamatok, alkalmaźás, új szempontok. Budapest: Urbis Könyvkiadó.

Fisman, S., Wolf, L., Ellison, D., Gillis, B., Freeman, T., \& Szatmari, P. (1996). Risk and protective factors affecting the adjustment of siblings of children with chronic disabilities. Journal of the American Academy of Child and Adolescent Psychiatry, 35, 1532-1541. doi. 10.1097/00004583-199611000-00023

Freud, S. (1958). Civilization and its discontents. New York: Doubleday Anchor Books.

Garrido, D., Petrova, D., Watson, L. R., GarciaRetamero, R., \& Carballo, G. (2017). Language and motor skills in siblings of children with autism spectrum disorder: A meta-analytic review. Autism Res., 10, (11), 1737-1750. doi. $\underline{10.1002 / \text { aur. } 1829}$

Hoffmann, M. L. (1991). Empátia, társas kogníció és morális cselekvés. In: Kulcsár Zs. (szerk.): 
Morális fejlōdés, empátia és altruizmus. Szöveggyüjtemény, (pp. 43-70). Budapest: ELTE Eötvös Kiadó.

Kádár A. (2012). Mesepszichológia. Az érzelmi intelligencia fejlesztése gyermekkorban. Budapest: Kulcslyuk Kiadó.

Kaminsky, L., \& Dewey, D. (2001). Siblings relationships of children with autism. Journal of Autism and Developmental Disorders, 31, (4), 399410. doi. $10.1023 / \mathrm{a}: 1010664603039$

Kanner, L. (1943). Autistic disturbances of affective contact. Nervous Child, 2, 217-250.

Lovell, B., \& Wetherell, M. A. (2016). The psychophysiological impact of childhood autism spectrum disorder on siblings. Research in Developmental Disabilities, 49, 226-234. doi. 10.1016/j.ridd.2015.11.023

MacLean, P. D. (1985). Brain evolution relating to family, play, and the separation call. Archives of General Psychiatry, 42, 405-417. doi. $10.1001 /$ archpsyc. 1985.01790270095011

Mayer, J. D. (2003). Útmutató az érzelmi intelligenciához. In: Ciarrochi, J., Forgas, J. P., Mayer, J. D. (szerk.): Érzelmi intelligencia a mindennapi életben. Budapest: Kairosz. Budapest. 23-49.

Mayer, J. D., Di Paolo, M. T., \& Salovey, P. (1990). Perceiving affective content in ambiguous visual stimuli: A component of emotional intelligence. Journal of Personality Assessment, 54, 772-781. doi. 10.1080/00223891.1990.9674037

McHale, S. M., Sloan, J., \& Simeonsson, R. J. (1986). Sibling relationships of children with autistic, mentally retarded, and nonhandicapped brothers and sisters. Journal of Autism and Developmental Disorders, 16, (4), 399-413.

Nagy H. (2010). A képesség-alapú érzelmi intelligencia modell érvényességének empirikus elemzése. Bölcsészdoktori disszertáció. Személyiség- és Egészségpszichológiai Program.

Nagy H. (2012). A Salovey-Mayer-féle érzelmi intelligencia modell érvényességének elemzése.
Magyar Pszichológiai Szemle, 67, (1), 105-124.

Oláh A. (2005). Érzelmek, megküzdés és optimális élmény. Belső világunk megismerésének módsz̨erei. Budapest: Trefort Kiadó.

Oláh A., G. Tóth K., \& Nagy H. (2005/a). Szociális kompetencia és érzelmi intelligencia feladatok 6-8 évesek. számára. Budapest: suliNova Kht.

Oláh A., G. Tóth K., \& Nagy H. (2005/b). Szociális kompetencia és érzelmi intelligencia feladatok 10-15 évesek sqámára. Budapest: suliNova Kht.

Roeyers, H., \& Mycke, K. (1995). Siblings of children with autism, with mental retardation and with normal development. Child: Care, Health \& Development, 21, 305-319.doi. 10.1111/j.1365-2214.1995.tb00760.x

Salovey, P., \& Mayer, J. D. (1990). Emotional intelligence. Imagination, Cognition and Personality, 9, 185-211.

Stone, W. L., McMahon, C. R., Yoder, P. J., \& Walden, T. A. (2007). Early SocialCommunicative and Cognitive Development of Younger Siblings of Children With Autism Spectrum Disorders. Archives of Pediatrics Adolescent Medicine, 161, 384-390. doi. $\underline{10.1001 / \text { archpedi.161.4.384 }}$

Szele, A. Sz. (2015). Érzelmi intelligencia és empátia vizsgálata autizmussal élők testvérei körében. Debreceni Egyetem. Mühelymunka.

Volkmar, F. R., \& Wiesner, L. A. (2013). Az autizmus kérikönyve. Amit minden szülönek, családtagnak, és tanárnak tudnia kell. Budapest: Autisták Országos Szövetsége.

Ward, B., Tanner, B.S., Mandleco, B., Dyches, T.T., \& Freeborn, D. (2016). Sibling Experiences: Living with Young Persons with Autism Spectrum Disorders. Pediatr Nurs., 42 (2), 69-76.

Zahn-Waxler, C., \& Radke-Yarrow, M. (1990). Az empátiás törődés eredete. In: Kulcsár Zs. (szerk.): Morális fejlödés, empátia és altruizmus. Szöveggyüjtemény, (pp. 71-90). Budapest: ELTE Eötvös Kiadó. 